\title{
Preparation of Sulfonated Poly (ethylene-co- tetrafluoroethylene-graft-styrene) Based Polymer Electrolyte Membranes for Fuel Cell by using Gamma Irradiation Technique
}

\author{
A. Suliwarno* \\ Center for the Application of Isotopes and Radiation Technology, National Nuclear Energy Agency \\ Jl. Lebak Bulus Raya No. 49, Jakarta 12440, Indonesia
}

\section{ARTICLE INFO}

Article history:

Received 20 November 2011

Received in revised form 28 March 2012

Accepted 30 April 2012

Keywords:

ETFE

Graft irradiation

Styrene

Electrolyte

Membrane

Fuel cell

\begin{abstract}
A B S T R A C T
Poly (ethylene-co-tetrafluoroethylene-graft-styrene-sulfonate) was successfully prepared by irradiation grafting of a styrene monomer into ethylenetetrafluoroethylene (ETFE) films and followed by sulfonation of the graft chains. Five film sheets of ETFE which having a size of $3 \mathrm{~cm} \times 8 \mathrm{~cm}$, thickness of $25 \mu \mathrm{m}$ were packed in vacuum using a $\mathrm{Y}$ type tube filled with argon gas. The samples were irradiated using $\gamma$-rays with a dose of $15 \mathrm{kGy}$ at $15 \mathrm{kGy} / \mathrm{h}$. The iradiated samples were grafted by using styrene monomer at $60^{\circ} \mathrm{C}$ for $1,3,5,7$ and $9 \mathrm{~h}$, respectively. The grafted samples (ETFE-g-St) were washed with xylene to remove homopolymer of polystyrene, and then its degree of grafting (DG) was determined. Sulfonation was carried out by using $0.2 \mathrm{M}$ chlorosulfonic acid in dichloroethane solution at a water bath of $60^{\circ} \mathrm{C}$ for $6 \mathrm{~h}$. Sulfonated samples (ETFE-g-St-SO ${ }_{3} \mathrm{H}$ ) were washed with water to neutralize its acidity, and dried in a vacuum drier at $40^{\circ} \mathrm{C}$ for $15 \mathrm{~h}$. The dried sample was weighed as sulfonated sample in order to determine the degree of sulfonation (\%DS). Membrane properties of EFTE-g-St-SO ${ }_{3} \mathrm{H}$ sample such as ion exchange capacity (IEC), proton conductivity in cross direction $\left(\sigma_{1}\right)$, and in-plane direction $\left(\sigma_{11}\right)$ were determined by using a HIOKI-3522 LCR HI tester. Durability test of samples were conducted in hot water and $3 \% \mathrm{H}_{2} \mathrm{O}_{2}$ respectively. The proton conductivity measurement and durability of the membrane were compared to Nafion $112 \AA$ as standard. The experimental results showed that the degree of grafting was increased with time of reaction for copolymerization, while $\%$ DS gave excellent results with an average of $92.7 \%$. The IEC value was more affected by the $\% \mathrm{DG}$ as compared to that of $\% \mathrm{DS}$ effect. The average of $\sigma_{1}$ value of the sample was $0.055 \mathrm{~S} / \mathrm{cm}$, compared to $\sigma_{1}$ of Nafion112® that was $0.066 \mathrm{~S} / \mathrm{cm}$. The average of $\sigma_{11}$ of the sample was $0.18 \mathrm{~S} / \mathrm{cm}$, while the $\sigma_{\text {II }}$ of Nafion $112 \AA$ was $=0.36 \mathrm{~S} / \mathrm{cm}$. The sample of SA004 with $53.49 \%$ DG was more stable than both the SA001 (21.48\%DG) and SA003 (41.52\% DG) in durability's test of the samples against hot water ( $334 \mathrm{~h}$ resistance). On the peroxides test, all of samples were degraded at $114 \mathrm{~h}$.
\end{abstract}

\section{INTRODUCTION}

Fuel cell is an electrochemical device that directly converts fuel such as $\mathrm{H}_{2}(\mathrm{~g})$ or methanol into an electrical current. It generates electricity inside a cell through reactions between a fuel and an oxidant. Fuel cells can operate continuously as long as the necessary reactant and oxidant flows are maintained. Many combinations of fuels and oxidants are possible, for example a hydrogen fuel cell uses hydrogen as fuel and oxygen as oxidant.

\footnotetext{
* Corresponding author.

E-mail address: ambyahs@batan.go.id
}

In a typical fuel cell, it consists of three main part namely the anode (negative electrode), electrolyte layer and the cathode (positive electrode) [1]. The electrolyte layer or electrolyte membrane can be made from modified polymer films which is synthesized such as by irradiation copolymerization method. The basic principle of this method is a hydrophobic polymer which has inductive effects such as fluorocarbon polymer that is grafted with hydrophobic monomer, then is followed by selective sulfonation of the grafted sample. Polymer electrolyte membrane (PEM) from sulfonated graft sample will attract the hydrogen ions, because its have the negative pole $\left(\mathrm{SO}_{3} \mathrm{H}^{-}\right)$on the end of grafted 
chain. Radiation graft copolymerization of styrene onto ETFE film with reaction mechanism of the sample is as follow;

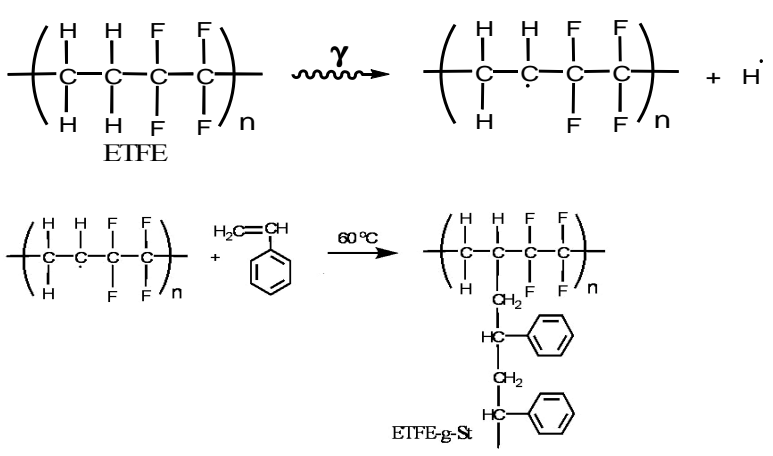

Degree of grafting (DG) of ETFE-g-St was determined by the equation as follows $[2,3]$;

$$
\operatorname{DG}(\%)=100 \times \frac{\mathrm{W}_{\mathrm{g}}-\mathrm{W}_{\mathrm{o}}}{\mathrm{W}_{\mathrm{o}}}
$$

where :

$\mathrm{W}_{\mathrm{o}} \quad$ = initial weight of film,

$\mathrm{W}_{\mathrm{g}}$ = weight of film after grafting.

Sulfonation of grafted sample is defined a chemical reaction involving the incorporated of sulfonic acid group, $-\mathrm{SO}_{3} \mathrm{H}$. The aim of this process is to made the cation exchanger sample due to the $-\mathrm{SO}_{3} \mathrm{H}$ group. For the grafted sample were readily sulfonated in next process, the sulfonates product behave as strong-acid ion exchangers [4]. The sulfonation process was illustrated with a reaction as follows;

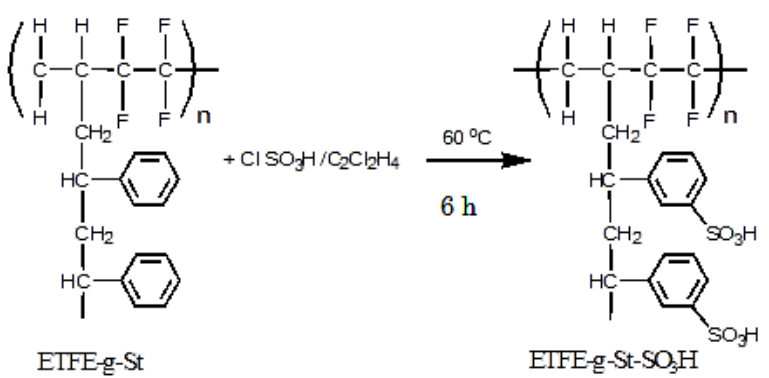

The Ion exchange capacity (IEC) of membrane is defined as the total number of chemical equivalents available for exchange per some unit weight or unit volume. IEC is the most important property of membrane in its application. The ideal fuel cell membranes should have low cost (less than $\$ 10 \mathrm{~kW}^{-1}$ in PEMFC), high ion exchange capacity, good chemical stability, and maintain mechanical integrity in hot water [5].

\section{EXPERIMENTAL METHODS}

\section{Materials}

Twenty five micrometer thick poly ethylene-co-tetrafluoroethylene (ETFE) films that was supplied by Asahi Glass Co. Ltd. were used as the base films for the preparation of polymer electrolyte membrane. This was done by irradiation grafting using styrene monomer from Wako Chemistry, and xylene for dilution of the polystyrene homopolymer. The chlorosulfonic acid and dichloroethane were used for sulfonation process, while $\mathrm{NaCl} 3 \mathrm{M}$ solution, $\mathrm{HCl} 0.1 \mathrm{M}$ solution, and $\mathrm{Na} \mathrm{OH} 0.1 \mathrm{M}$ solution were used for determination of IEC membrane. According to IEC measurement, the following cationic exchange mechanisms between $\mathrm{H}^{+}$and $\mathrm{Na}^{+}$were shown in these reactions:

ETFE-graft-St-SO $\mathrm{S}_{3} \mathrm{H}+\mathrm{NaCl} \longrightarrow$ ETFE-graft-St-SO ${ }_{3} \mathrm{Na}+\mathrm{HCl}$ $\mathrm{HCl}+\mathrm{NaOH} \longrightarrow \mathrm{NaCl}+\mathrm{H}_{2} \mathrm{O}$

IEC was calculated by using titration results as follows;

$\mathrm{IEC}=1000 \times \frac{\mathrm{M}_{\mathrm{NaOH}} \times \mathrm{V}_{\mathrm{NaOH}}}{\mathrm{W}_{\text {as }}}, \mathrm{mmol} / \mathrm{g}$

$\mathrm{M}_{\mathrm{NaOH}}=$ Concentration of $\mathrm{Na} \mathrm{OH}$ solution. (0.1)

$\mathrm{V}_{\mathrm{NaOH}}=$ Volume of $\mathrm{NaOH}$ solution used in titration, $\mathrm{ml}$

Was = Weight of membrane after sulfonation, $\mathrm{mg}$

\section{Method}

The experiment was conducted at the laboratory of Conducting Polymer Materials Group, Environment and Industrial Materials Research Division, Quantum Beam Science Directorate, Takasaki Advanced Radiation Research Institute-Japan Atomic Energy Agency, Japan. Five sheets of ETFE films $(3 \mathrm{~cm} \times 8 \mathrm{~cm}$, $25 \mu \mathrm{m}$ thickness) were packed in a vacuumized Y type tube (Fig. 1.), then argon gas was filled into the tube. These samples were irradiated using $\gamma$-rays with an absorbed dose of $15 \mathrm{kGy}$ at $15 \mathrm{kGy} / \mathrm{h}$. After irradiation, the films were grafted by adding styrene monomer into the tube on water bath at $60^{\circ} \mathrm{C}$ for $1,3,5,7$ and $9 \mathrm{~h}$. The grafted samples were washed with toluene to remove the polystyrene homopolymer, then washed in water subsequently dried in a vacuum oven at $40^{\circ} \mathrm{C}$ for $16 \mathrm{~h}$. 

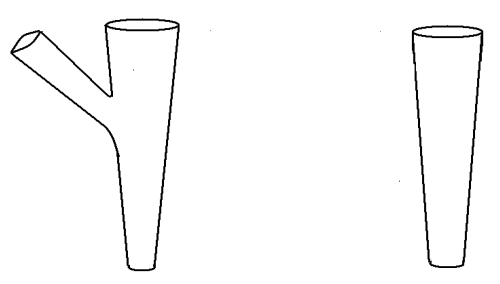

Fig. 1. The Y type tube (left), the main hole use for vacuum and filling argon gas, the side hole for adding the monomer and other I type tube (right [8]).

\section{Sulfonation of grafted sample}

Sulfonation was carried out by using $0.2 \mathrm{M}$ chlorosulfonic acid in dichloroethane solution on a water bath at $60^{\circ} \mathrm{C}$ for $6 \mathrm{~h}$. The sulfonated samples were washed with water until the $\mathrm{pH}$ of the water was 7 , and dried in a vacuum drier at $40^{\circ} \mathrm{C}$ for $15 \mathrm{~h}$, then weighed.

\section{lon exchange capacity (IEC)}

In order to determine IEC, the EFTE-g-St$\mathrm{SO}_{3} \mathrm{H}$ membrane was immersed in $3 \mathrm{M} \mathrm{NaCl}$ aq. solution in a closed bottle, and then was shaken using TAITEC Recipro Shaker RN-1 over night. After taking out the membrane, the solution was titrated with $0.1 \mathrm{~N} \mathrm{NaOH}$ solutions by using an automatic titrator HIRANUMA COM-2000 apparatus.

The Degree of sulfonation is defined as the comparison between sulfonated results and the $100 \%$ sulfonation which is determined by using the above titration factors in the following equation:

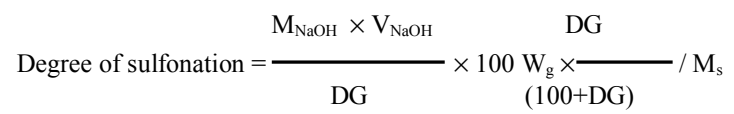

Where:

$\mathrm{DG}=$ Degree of grafting, \%

$\mathrm{W}_{g}=$ Weight of grafted membrane, $\mathrm{g}$

$\mathrm{M}_{\mathrm{St}}=$ Molecular weight of styrene (104).

\section{Proton conductivity measurement}

Proton conductivity is defined as the capability of material (usually solid electrolyte) to transfer a number of hydrogen ions (protons). The proton conductivity of ETFE-g-St- $\mathrm{SO}_{3} \mathrm{H}$ at $25^{\circ} \mathrm{C}$ was obtained by using HIOKI-3522 LCR HI tester apparatus. The films were hydrated in water overnight before measurement, and clamped between two Pt electrodes during measurement.
The proton conductivity of the film in the inplane direction $\left(\sigma_{11}\right)$ is calculated by using the following equation [6]:

$$
\sigma_{11}[\mathrm{~S} / \mathrm{cm}]=\frac{\mathrm{W}[\mathrm{cm}]}{\mathrm{A}[1 / \mathrm{S}] \times \mathrm{L} \times \mathrm{d}[\mathrm{cm}]}
$$

where :

$\mathrm{A}[1 / \mathrm{S}]$ is the measured resistance of the film , $\mathrm{W}=(0.33 \mathrm{~cm})$ is the gap length between two electrodes,

$\mathrm{L}[\mathrm{cm}]$ is the film width, and $\mathrm{d}(\mathrm{cm}]$ is the film thickness.

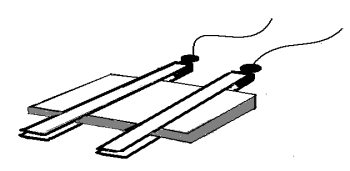

Fig. 2. Schematic method of measurement ion conductivity in the in-plan direction.

The ion conductivity of the film in the vertical/cross direction $\left(\sigma_{1}\right)$ is calculated by utilizing the following equation:

$\sigma_{1}[\mathrm{~S} / \mathrm{cm}]=\frac{\mathrm{d}[\mathrm{cm}]}{B[1 / \mathrm{S}] \times \mathrm{S}\left[\mathrm{cm}^{2}\right]}$

Where:

$\mathrm{B}[1 / \mathrm{S}]$ is resistance of the film, $\mathrm{d}(\mathrm{cm})$ is the film thickness,

$\mathrm{S}\left(\mathrm{cm}^{2}\right)$ is the area of the film contacting the electrode. Here $\mathrm{S}\left(\mathrm{cm}^{2}\right)$ is calculated from the measured resistance $C[1 / \mathrm{S}]$ of Nafion whose ion conductivity is known at

$$
\begin{aligned}
& \sigma_{1}=(0.066) \frac{1}{\mathrm{~S}} \text {, using the following equation: } \\
& \begin{aligned}
\mathrm{S}\left[\mathrm{cm}^{2}\right] & =\frac{\mathrm{d}_{\text {Nafion }}[\mathrm{cm}]}{\mathrm{C}[1 / \mathrm{S}] \times \sigma_{1}[1 / \mathrm{S}]} \\
& =\frac{0.0060[\mathrm{~cm}]}{9.1[1 / \mathrm{S}] \times 0.066[1 / \mathrm{S}]} \\
& =0.0100 \mathrm{~cm}^{2}
\end{aligned}
\end{aligned}
$$




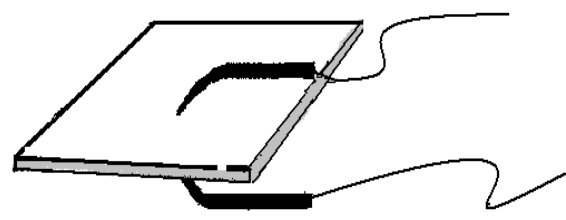

Fig. 3. Schematic method of measurement ion conductivity in the cross direction.

\section{Durability of ETFE-g-St-SO $\mathrm{S}_{3} \mathrm{H}$ membrane against hydrogen peroxide and hot water}

The durability of the membrane against peroxide was investigated as a degradation factor of polymer electrolyte membrane fuel cell (PEMFC) because it played an important role in the application of the membrane. During the durability tests, three sheets of poly (ethylene-cotetrafluoroethylene) films grafted with copoly (p-sulfostyrene) sulfonate (ETFE-g-St-SO ${ }_{3} \mathrm{H}$ ), namely SA003, SA005, and SA007, which have grafting degrees of $69.3 \%, 30.0 \%$ and $51.7 \%$ respectively, were immersed in $3 \% \mathrm{H}_{2} \mathrm{O}_{2}$ aqueous solution at $60^{\circ} \mathrm{C}$. After several hours, the membrane samples were taken out from the solution, and weighed after wiping out the remaining water on the surfaces. The immersion process of samples was continued until a constant weight of samples were achieved. For durability in hot water, the same samples mentioned above were immersed in $\mathrm{H}_{2} \mathrm{O}$ and kept at $80^{\circ} \mathrm{C}$. With the same manners, the weights of these samples were determined after immersion for several hours until a constant weight was found.

\section{RESULTS AND DISCUSSION}

\section{Radiation graft copolymerization styrene onto ETFE film}

One of the first experiments was done in order to determine relationship between degree of grafting and time of reaction. Five pieces of irradiated ETFE film were grafted at $9 \mathrm{~h}$ of reaction time. Figure 1 shows that the degree of percent grafting was increased by longer reaction time. The curve seemed to plateau after $7 \mathrm{~h}$ of reaction time. The phenomena might be due to the saturation after $7 \mathrm{~h}$. From this kind of irradiated samples, the reaction time of $7 \mathrm{~h}$ was suggested, and chosen as the optimum time for irradiation graft copolymerization.

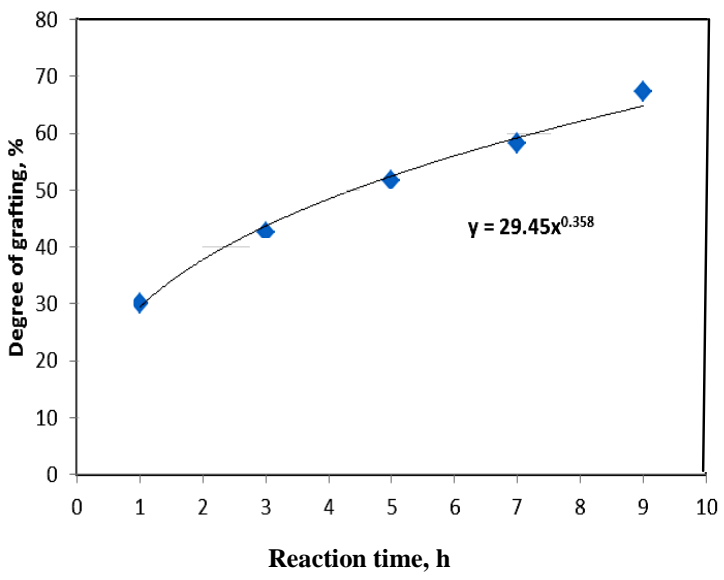

Fig. 4. Effect of reaction time on the degree of grafting styrene onto ETFE film irradiated with the dose of $15 \mathrm{kGy}$.

\section{Sulfonation of grafted ETFE-g-St film}

Sulfonation of ETFE-g-St is a nucleophylic substitution process which is a fundamental class of substitution reaction, in which an electron rich nucleophile, attacks the positively charge atoms or group. The positive charge is the $\mathrm{H}^{+}$and the nucleophilic is sulfonate group $\left(-\mathrm{SO}_{3} \mathrm{H}^{-}\right)$. Table 1 shows that grafting reaction was successfully, then the next reaction (sulfonation) to be done with a degree of the sulfonation has an average of $91.7 \%$. It was seen that $\%$ sulfonation did not depend on $\%$ $\mathrm{DG}$, and the high value of $\%$ sulfonation was due to the involvement of a strong ionic properties between the $\mathrm{H}^{+}$and the nucleophilic group [7].

Table 1. Degree of grafting and degree of sulfonation and IEC of ETFE-g-SO $\mathrm{SO}_{3} \mathrm{H}$

\begin{tabular}{cccc}
\hline $\begin{array}{c}\text { Sample } \\
\text { No. }\end{array}$ & $\begin{array}{c}\text { Degree of } \\
\text { grafting, } \%\end{array}$ & $\begin{array}{c}\text { Degree of } \\
\text { Sulfonation, } \%\end{array}$ & $\begin{array}{c}\text { IEC, } \\
\mathrm{mmol} / \mathrm{g}\end{array}$ \\
\hline SA001 & 52.2 & 76.9 & 2.00 \\
SA002 & 48.6 & 98.2 & 2.33 \\
SA003 & 69.3 & 86.7 & 2.36 \\
SA004 & 67.3 & 89.7 & 1.75 \\
SA005 & 30.0 & 96.4 & 1.58 \\
SA006 & 58.2 & 96.1 & 2.19 \\
SA007 & 51.7 & 97.9 & 2.13 \\
\hline
\end{tabular}

\section{Determination of Ion exchange capacity}

The total capacity of ion exchange of a membrane is defined as the total number of chemical equivalents available for exchange per some unit of weight. Concerning IEC of ETFE-g$\mathrm{St}-\mathrm{SO}_{3} \mathrm{H}$, it can be seen that IEC was increased by the increasing degree of grafting. This is due to the 
active group of ionic exchange that exist on the graft chain. Thus, the IEC property will arise when the bulk polymer had certain value of $\% \mathrm{DG}$. On the other hand, the IEC is the function of existence of sulfonate group, it means that the IEC would increase with the higher of \% sulfonation. Figure 6 shown

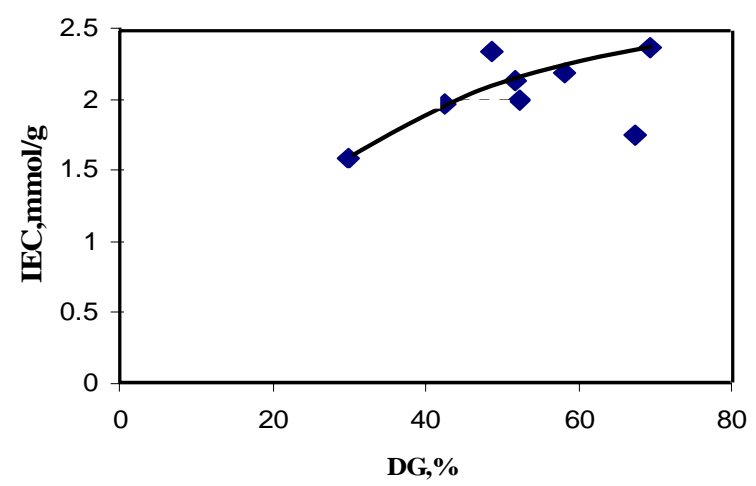

Fig. 5. Effect of degree of grafting styrene onto IEC of ETFEg-St-SO ${ }_{3} \mathrm{H}$.

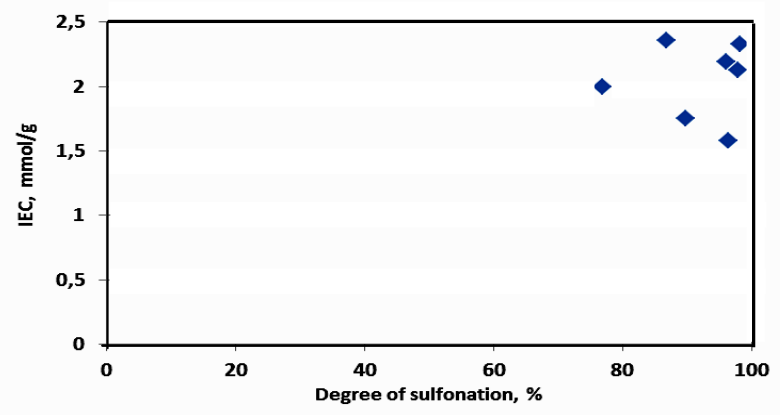

Fig. 6. Effect of degree of sulfonation versus IEC of ETFE-g$\mathrm{St}-\mathrm{SO}_{3} \mathrm{H}$.

that group of points \% degree of sulfonation Vs. IEC which is located in the upper right, that is meant where IEC is a factor of the presence of $\%$ degree of sulfonation.

The proton or ion conductivity from the samples were measured by using Nafion $112 \AA$ as a standard. Here S, contacting area $\left(\mathrm{cm}^{2}\right)$ is calculated from the measured IEC $(1 / \mathrm{S})$ of Nafion $112 \AA$ whose ion conductivity is known at $\sigma_{1} 0.066(1 / \mathrm{S})$, using the equation [7]. The results of sample measurement was shown in the following Table.

Some of the values of cross direction conductivity $\left(\sigma_{1}\right)$ in Table 2 were undervalued as compared to that of Nafion $112 \AA$. This is possibly due to a different type of structure where the ETFEg-St- $\mathrm{SO}_{3} \mathrm{H}$ membrane contained the aromatic group, whereas Nafion $112 \AA$ is composed of the aliphatic. The aromatic organic compound were contained many $\pi$ electron which are delocalized around of the ring bond. This condition makes it unstable toward some of chemical effect compared to that of aliphatic organic compound.

Table 2. In-plane direction $\left(\sigma_{11}\right)$ and cross direction $\left(\sigma_{1}\right)$ conductivities of ETFE-g-St- $\mathrm{SO}_{3} \mathrm{H}$.

\begin{tabular}{|c|c|c|c|c|c|c|c|}
\hline Sample No & $\begin{array}{c}\text { A, } \\
\text { ohm }\end{array}$ & $\begin{array}{c}\text { B, } \\
\text { ohm }\end{array}$ & $\begin{array}{l}\mathrm{L}, \\
\mathrm{cm}\end{array}$ & $\begin{array}{l}\text { d (tick- } \\
\text { ness),ccm }\end{array}$ & $\begin{array}{c}\mathrm{S}, \\
\mathrm{cm}^{2}\end{array}$ & $\begin{array}{c}\sigma_{11} \\
{[\mathrm{~S} / \mathrm{cm}]}\end{array}$ & $\begin{array}{c}\sigma_{1} \\
{[\mathrm{~S} / \mathrm{cm}]}\end{array}$ \\
\hline Nafion $112 ®$ & 388.5 & 9.1 & 2.05 & 0.0060 & 0.10 & 0.36 & 0.066 \\
\hline SA001 & 211.0 & 9.0 & 2.41 & 0.0040 & 0.10 & 0.16 & 0.040 \\
\hline SA002 & 176.7 & 5.6 & 2.63 & 0.0033 & 0.10 & 0.22 & 0.060 \\
\hline SA003 & 143.3 & 5.7 & 2.48 & 0.0038 & 0.10 & 0.24 & 0.070 \\
\hline SA004 & 158.2 & 6.0 & 1.97 & 0.0050 & 0.10 & 0.21 & 0.080 \\
\hline SA005 & 258.7 & 8.1 & 2.32 & 0.0039 & 0.12 & 0.10 & 0.020 \\
\hline SA006 & 173.1 & 6.7 & 2.29 & 0.0049 & 0.12 & 0.17 & 0.060 \\
\hline SA007 & 171.4 & 6.5 & 2.10 & 0.0049 & 0.12 & 0.19 & 0.060 \\
\hline$\sim\left(\mathrm{CF}_{2}-\mathrm{C}\right)$ & 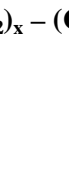 & $\begin{array}{l}{ }_{2}^{2-C F} \\
\text { O- }\end{array}$ & & $\left.\mathrm{F}_{2}-\mathrm{CF}\right)_{\mathrm{m}}$ & \multicolumn{3}{|c|}{$\begin{array}{c}-\mathrm{O}-\left(\mathrm{CF}_{2}\right)_{\mathrm{n}}-\mathrm{SO}_{3} \mathrm{H} \\
\underset{\mathrm{CF}_{3}}{ }\end{array}$} \\
\hline
\end{tabular}

Fig. 7. The general structure of Nafion ${ }^{\circledR}$ (Du Pont) [6].

\section{Durability of ETFE-g-St-SO ${ }_{3} \mathrm{H}$ membrane}

According to the durability test in hot water (Fig. 8.), refering to sample SA003 with higher $\%$ DG of $69.9 \%$, the sample weight was sharply decreased until $120 \mathrm{~h}$, as compared to SA005 and SA007 with $30 \%$ and $51.7 \%$ of $\%$ DG respectively. After $174 \mathrm{~h}$ of immersion, the SA003 sample reached a constant weight, and it was afloat on the water. On the other hand, the sample with lower $\%$ DG (SA005) showed the monotonous drop until 286 hour of immersion and then reached a constant weight. It was also noted that sample SA 007 showed the lowest decrease in weight, and it achieved a constant weight after $334 \mathrm{~h}$ immersion.

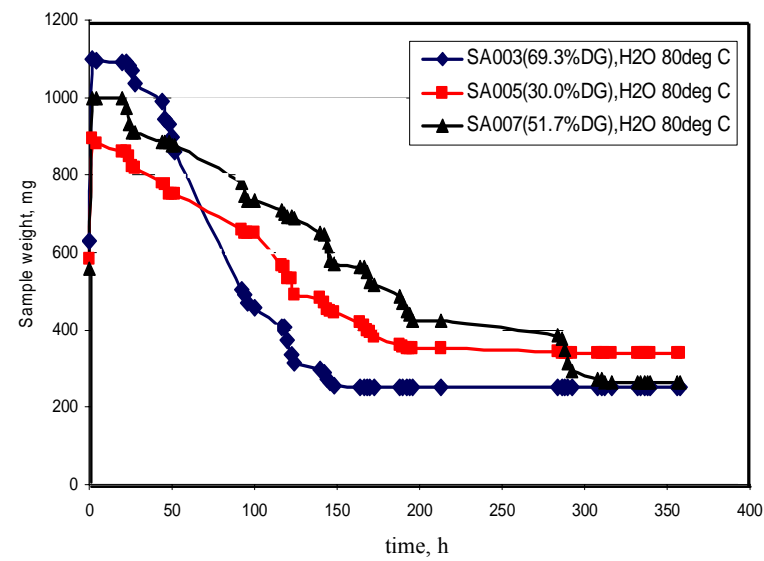

Fig. 8. Lost weight of ETFE-g-St- $\mathrm{SO}_{3} \mathrm{H}$ membrane after immersing in $\mathrm{H}_{2} \mathrm{O}$ at $80^{\circ} \mathrm{C}$. 
From the curve of Fig. 8, all of membrane samples were susceptible to the oxidation degradation in $3 \% \mathrm{H}_{2} \mathrm{O}_{2}$ solution. The samples were totally degraded after immersion for about $36 \mathrm{~h}$. The sample with low \%DG such as SA005 (30.0\%) degraded faster than that of the higher \%DG. The constant weight of the samples at the end of the $36 \mathrm{~h}$ indicated that the degradation was that complete. In the final step, the floating of the samples on the $\mathrm{H}_{2} \mathrm{O}_{2}$ solution occurred, due to the disappearance of the hydrophilic properties.

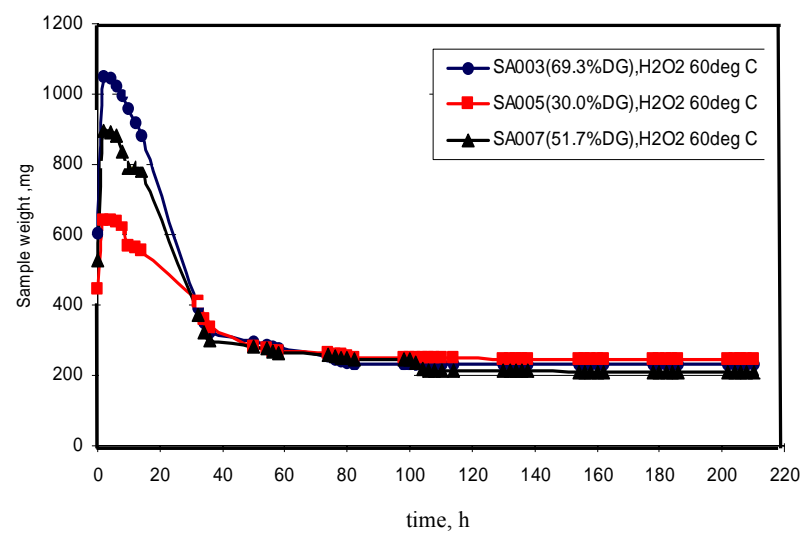

Fig. 9. Lost weight of ETFE-g-St- $\mathrm{SO}_{3} \mathrm{H}$ membrane after immersing in $3 \% \mathrm{H}_{2} \mathrm{O}_{2}$ at $60{ }^{\circ} \mathrm{C}$.

The possible mechanism of sample degradation process by peroxide was suggested in the following reaction:

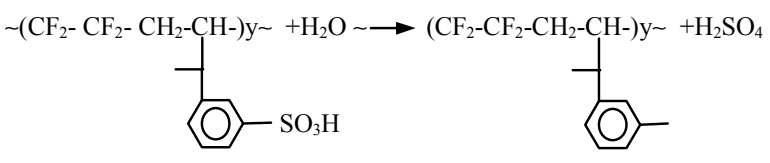

ETFE-g-St-SO3H membrane

degraded membrane

\section{CONCLUSION}

From the experiment, it can be concluded that radiation graft copolymerization of styrene onto ETFE film was done successfully with the following membrane properties:

The sulfonation process by using $0.2 \mathrm{M}$ sulfonic acid in dichloroethane was done with a degree of ETFE-g-St sample at $91.7 \%$.
The IEC of membrane increased with increasing of $\% \mathrm{DG}$, and did not seem to correlate with the $\% \mathrm{~S}$.

The cross direction conductivities of membranes $\left(\sigma_{1}\right)$, was similar to the value of that of nafion-112® ie. $0.066 \mathrm{~S} / \mathrm{cm}$, and the results of inplane direction conductivities $\left(\sigma_{11}\right)$ showed a substantially lower value than that of nafion-112®.

\section{ACKNOWLEDGEMENT}

The author wish to thank Yasunari MAEKAWA Ph. D., Head of Conducting Polymer Materials Group, Environment and Industrial Materials Research Division, Quantum Beam Science Directorate, JAPAN ATOMIC ENERGY AGENCY where this research has been carried out.

\section{REFERENCES}

1. Anonymous, Fuel Cell 2000 Basics Benefits and Fuel Cell Today. Retrieved in July (2009).

2. J. Chen, M. Asano, T. Yamaki and M. Yoshida, J. Power Sources 158 (2006) 69.

3. J. Chen, U. Septiani, M. Asano and Y. Maekawa, J. Appl. Polym. Sci. 103 (2007) 1966.

4. Y. Chao-Yeuh and C. Abraham, React. Polym., Ion Exch., Sorbents 5 (1987) 13.

5. S. Li-Chen, L. Krishnan, S. Srinivasan, J. Benziger and A.B. Bocarsly, J. Membr. Sci. 243 (2004) 327.

6. S. Upita, J. Chen, M. Asano, T. Yamaki, Y. Maekawa and M. Yoshida, J. Mater. Sci. 42 (2007) 1330.

7. Anonymous, http://en.wikipedia.org/wiki/Nucleophilic_substitution). Retrieved in october (2010).

8. S. Hasegawa, Y. Suzuki and Y. Maekawa, Radiat. Phys. Chem. 77 (2008) 617. 